\title{
Understanding NTMs between Indonesia and India for Development Strategies of Trade
}

\author{
Kumara Jati \\ Trade Analysis and Development \\ Agency \\ Ministry of Trade, Indonesia \\ Jakarta, Indonesia \\ kumara_jati@yahoo.com \\ Endah Ayu Ningsih \\ Trade Analysis and Development \\ Agency \\ Ministry of Trade, Indonesia \\ Jakarta, Indonesia \\ ayuningsih.endah@gmail.com
}

\author{
Arie Mardiansyah \\ Trade Analysis and Development \\ Agency \\ Ministry of Trade, Indonesia \\ Jakarta, Indonesia \\ arie.mardiansyah@ymail.com \\ Steven Raja Ingot \\ Trade Analysis and Development \\ Agency \\ Ministry of Trade, Indonesia \\ Jakarta, Indonesia \\ sri.bako@gmail.com
}

\author{
Leo Mualdy Christoffel \\ Trade Analysis and Development \\ Agency \\ Ministry of Trade, Indonesia \\ Jakarta, Indonesia \\ leo_m_c_siagian@yahoo.com
}

\begin{abstract}
Understanding Non Tariff Measures (NTMs) principles enable someone to identify forms of policies other than import tariffs. NTMs are generally enforced to protect domestic producers and consumers in accordance with international rules and principles. Indonesia and India are the $4^{\text {th }}$ and $2^{\text {nd }}$ most populous country in the world. Therefore, these countries are interesting subjects to see how NTMs are being implemented. The Normative Juridical Analysis of NTMs found that India has applied more Sanitary and Phytosanitary (SPS) policy to other countries, but Indonesia has applied more Technical Barriers to Trade (TBT) policy to other countries. On Bilateral Trade between India and Indonesia, India has applied more Contingent Trade Protective Measures (CTPM) to Indonesia, but Indonesia has applied more Sanitary and Phytosanitary (SPS) to India. The descriptive analysis of NTMs show that Indonesia and India need to apply internationally accepted standard and treatment on its exported products, both agriculture and non-agriculture, to avoid unnecessary interception and rejection of entry to each other custom territory. Development strategies of trade that can be implemented as follows: (1) remove NTBs and streamline NTMs; (2) encourage trade facilitation; (3) address NTMs to protect the safety of humans, animals, plants and to improve the quality of life.
\end{abstract}

Keywords-Bilateral Indonesia and India, Development Strategies of Trade, Normative Juridical Analysis, Descriptive Analysis of NTMs

\section{INTRODUCTION}

Bilateral Trade Agreement (BTA) is a formal collaboration between two countries to reduce tariffs and Non-Tariff Barriers (NTBs). The dynamic impact of BTAs that will be received in the medium and long-run term is predicted to have a wider and greater effect in influencing the welfare and economy of a country. Some of the most important effects in the context of BTAs including achieving Foreign Direct Investment (FDI), economic growth, economies of scale, structural policy changes, technology transfer, and increasing of competitiveness in the long period of time.

BTA also is one form of reaction to the existence of liberalization and globalization, which has implication for elimination and reduction of various obstacles in trade activities both tariff barriers and Non-Tariff Barriers (NTBs). NTBs is non-tariff distortion as any measures (public or private) that causes internationally traded services and goods, to be allocated in such a way as to reduce the potential real income of the world [1].

NTBs is different with Non-Tariff Measures (NTMs). In general, NTMs include all policy-related trade costs incurred from production to final consumer, with the exclusion of tariffs, and categorized depending on the scope/design and broadly distinguished in technical measures (SPS, TBT, preshipment inspections) and non-technical measures [2]. In other words, NTMs are all forms of policy other than import tariffs in general, which potentially have an economic impact on trade in goods and services between countries, by affecting the traded quantity, price, or both. The examples of NTMs are: product specific quotas, quality condition, minimum import price, import prohibitions, antidumping measures, SPS requirements, foreign exchange market control, and import license. Although, there are some measures, not included in NTMs: private standard, inadequate infrastructure, procedural obstacle, and production standard.

According to UNCTAD (2013), NTMs severely restrict international trade and its contribution to overall trade restrictions is generally far greater than tariffs [2]. Sometimes, NTMs incorrectly referred the same as NonTariff Barriers (NTBs) and it is difficult to distinguish NTBs from NTMs. The difference is that NTMs comprise a wider set of measures than NTBs. NTMs can become NTBs in three conditions: (1) it affects trade more than is necessary to overcome the trade domestic issue, (2) it effect quantity traded and/or prices and have proven discriminatory, (3) it has an intent to be protectionist. Although, some of the trade research literature explains that both NTMs and NTBs are used interchangeably and the distinction is quite vague [3].

Based on the economic and trade data, India is the largest trade partner of ASEAN region with a trading value in the last 5 years increased by $5.3 \%$ from USD 16.2 billion in 2014 to USD 18.7 billion in 2018. India is the number one 
destination of Indonesian strategic commodity export product such as palm oil at USD 5.16 billion in 2017. Both countries have given the total target trade value to USD 50 billion in the year 2025 . India is the $5^{\text {th }}$ largest economic power in the world with total GDP reaching USD 2.65 trillion and having the second fastest economic growth at the level of $7.2 \%$ [4]. In the year 2023, it is estimated that India will reach GDP 5 trillion and by the year 2030 will become the world's second largest economic power in the world.

Some research papers have discussed issues related to trade development strategies. Gorener (2012) wrote about strategic decisions that provide operational actions that are appropriate for the market at the right time [5]. Trade Analysis and Development Agency proposed a study that give five criteria for the formulation of Indonesia's export development strategy, which are: (1) expansion of private trading companies; (2) coordination of Indonesian Embassies and Consulates with Ministry of Trade in market intelligence; (3) product design creativity; (4) improve product quality in accordance with the standards of destination countries; (5) establishment of outlets in destination countries that sell Indonesian products [6]. Moreover, India's development strategies of trade is not always clear. The position at WTO eventually remain conservative. India has a "defensive" stance on agriculture and an "offensive" stance on service, but the underlying rationale is not too explicit [7].

Moreover, due to the implementation of ASEAN-India Free Trade Agreement [30], tariffs between Indonesia and India are constantly being cut. Therefore, the policy makers of the two countries are employing other measures to protect domestic trade such as Non-Tariff Measures. When multilateral and regional agreements are increasing and tariffs in international trade are gradually being eliminated, the policy makers around the world are focusing on using Non-Tariff Measures (NTMs) in their trade. The above mentioned explanation shows that not many researchers examine the understanding of NTMs between Indonesia and India for developing strategies of trade, which left a place to fill the opportunity for new research paper. Therefore, the purpose of this paper is to analyze the NTMs application between Indonesia and India for developing strategies of trade using normative juridical analysis and descriptive analysis of NTMs.

\section{METHODS}

\section{Normative Juridical and Descriptive Analysis}

The normative juridical analysis is a model that examines the understanding of the implementation and legislation approach. This paper used the model to focus on reviewing regulations and laws related to the Non-Tariff Measures (NTMs) especially in India and Indonesia. Moreover, the implementation approach, focus on reviewing the practice of regulations and laws in Indonesia and India for development strategies. The descriptive analysis is presented in the form of data tabulation consisting of regulatory alignment, regulatory substance, and the relevance to the practiced implementation [25].

The normative juridical and descriptive analysis also can be based on the identification of NTMs refer to the UNCTAD classification in the year 2012. The definition of
NTMs itself can have an economic influence on international trade commodity or can cause distortion, thereby reducing the potential benefits of international trade [2]. The classification of NTMs is divided into import measures and export measures. Import measures are divided into two parts, namely technical measures and non-technical measures; while export measures only have one classification, namely export related measures.

Four research reports (Embassy of India, 2018; Purnamawati et al., 2016; Jati, K., 2019a; Jati, K., 2019b) used normative juridical and descriptive analysis in Indonesia and India [8] [9] [28] [29]. The regime of national policies and regulations in India focused on promoting strategic export domestic industries and exports, protection of local markets for domestic products, safeguarding against hazard to public health, environment, and perceptions of social-political-religious and security issues [10]. Moreover, Indonesia as a part of the ASEAN region, the NTMs can be seen in a group of 10 countries. The ASEAN countries' average tariff rates decreased from 8.9 percent in the year 2000 to 4.5 percent in the year of 2015 , but the NTMs number increased from 1,634 measures to 5,975 measures in the same period of time, although a country with a relatively higher measure number does not mean it is relatively more protectionist than other countries [11].

Primary data collection was conducted through discussion and interviews from respected authorities, business entities and government that know about NTMs. The researcher through the purposive sampling method of informant selecting certain expert that willing to share their knowledge and experience with NTMs policy The result of primary data collection is confirmed by a group of expert in Indonesia and India related to NTMs. It is highly relevant to select good informant and using purposive sampling technique is one of the most effective ways to study a certain domain with knowledgeable experts within [12]. Secondary data are obtained from books, articles, journal and other scientific literature that has a good reference for NTMs.

\section{RESULT AND DISCUSSION}

Indonesia is a key economic partner for India in Southeast Asia with bilateral trade of almost US\$ 20 billion in 2018, Indonesia is the $4^{\text {th }}$ largest trading destination for India in the ASEAN region. Compared to trade in 2005, the export Indonesia to India has witnessed almost fivefold in 2018. From USD 2.9 billion in 2005 to USD 13.7 billion in 2018. India is also the main export destination country of Indonesia with exports to India equivalent to $8 \%$ of Indonesia's total exports to the world. Indonesia's exports to India have increased rapidly over the past 10 years with an average growth of $11.5 \%$ per year (see figure 1). The most significant increase in export was after the entry into force of the ASEAN-India Free Trade Agreement in 2010. 


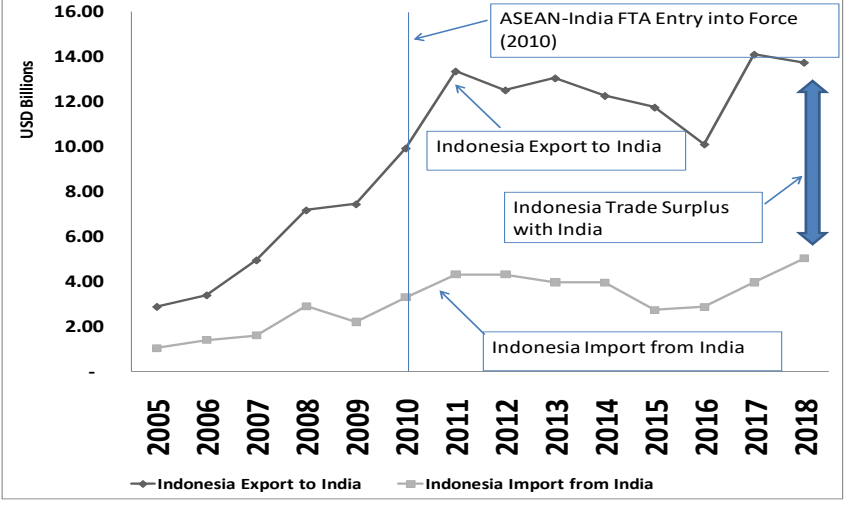

Source: WITS, 2019 and PresPres No.27 Year 2010 [30]

Fig. 1. Indonesia Trade with India

India is the second largest buyer of coal and crude palm oil from Indonesia. Indonesia export crude palm oil to India reached USD 2.2 billion in 2018 which is more than $60 \%$ from Indonesia's total export to the world. Other Indonesia main export products to India are minerals, rubber, pulp and paper, and hydrocarbon reserves. India exports refined petroleum products, commercial vehicles, telecommunication equipment, bovine meat, animal feed, agriculture products, steel and plastics to Indonesia.

India's export to Indonesia 2017 was mainly due to the export of bovine meat which was facilitated by the Government Regulation Republic of Indonesia (Peraturan Pemerintah/PP) Number 4 year 2016 [13] issued in March 2016 that expands cattle import zones from so far as to be a country based (zone based), Indonesia can import cattle from any country, including India. In its implementation, only State-Owned Enterprises (BUMN and BUMD) are authorized to import cattle and beef. In an audit by a team from Ministry of Agriculture of Republic of Indonesia in India in March 2018, 19 new bovine meat plants and 3 dairy plants were approved for exporting to Indonesia. So, this figure is expected to increase in the coming financial year. There is considerable potential for expanding trade between the two countries in the areas of pharmaceuticals, automotive components, automobiles, engineering products, IT, biotechnology and healthcare services.

The total trade between Indonesia and India to the world can provide a clear picture of the importance of Bilateral Trade between these two countries (see table 1). In Indonesia's perspective, India's position as a trading partner is becoming increasingly important. The role of India in Indonesia's export destinations has consistently increased from 2005 to 2018. The negative growth of the value of Indonesia's exports to India is a reflection of the global economic situation that is in crisis and does not indicate that Indonesia's interest in India has diminished. On the contrary, from India's point of view, Indonesia's role as a trading partner tends to be stagnant as indicated by the share of Indian exports to Indonesia to its total exports relatively stable during the period 2005 to 2018 .
TABLE 1. INDONESIA AND INDIA TRADE WITH THE WORLD

\begin{tabular}{ccccccc}
\hline Year & $\begin{array}{c}\text { Indonesia } \\
\text { Export to } \\
\text { India } \\
\text { USD } \\
\text { Billion }\end{array}$ & $\begin{array}{c}\text { Share } \\
\text { from } \\
\text { Indonesia } \\
\text { Export to } \\
\text { World } \\
(\%)\end{array}$ & $\begin{array}{c}\% \\
\text { Growth }\end{array}$ & $\begin{array}{c}\text { India } \\
\text { Export to } \\
\text { Indonesia } \\
\text { USD } \\
\text { Billion }\end{array}$ & $\begin{array}{c}\text { Share } \\
\text { from } \\
\text { India } \\
\text { Export to } \\
\text { World } \\
(\%)\end{array}$ & $\begin{array}{c}\% \\
\text { Growth }\end{array}$ \\
\hline 2005 & 2.88 & 3.4 & & 1.39 & 1.4 & \\
2006 & 3.39 & 3.4 & 17.8 & 1.87 & 1.5 & 34.5 \\
2007 & 4.94 & 4.3 & 45.8 & 1.88 & 1.3 & 0.4 \\
2008 & 7.16 & 5.2 & 44.9 & 2.66 & 1.5 & 41.6 \\
2009 & 7.43 & 6.4 & 3.8 & 3.00 & 1.7 & 12.9 \\
2010 & 9.92 & 6.3 & 33.4 & 4.56 & 2.1 & 51.8 \\
2011 & 13.34 & 6.6 & 34.5 & 6.40 & 2.1 & 40.4 \\
2012 & 12.50 & 6.6 & -6.3 & 6.02 & 2.1 & -5.9 \\
2013 & 13.03 & 7.1 & 4.3 & 5.56 & 1.7 & -7.7 \\
2014 & 12.25 & 7.0 & -6.0 & 4.44 & 1.4 & -20.0 \\
2015 & 11.73 & 7.8 & -4.2 & 2.87 & 1.1 & -35.5 \\
2016 & 10.09 & 7.0 & -14.0 & 3.13 & 1.2 & 9.2 \\
2017 & 14.08 & 8.3 & 39.5 & 3.76 & 1.3 & 20.2 \\
2018 & 13.73 & 7.6 & -2.5 & 4.79 & 1.5 & 27.3 \\
\hline
\end{tabular}

Table 2 shows that most of the India's Tariff are less than 10 percent or approximately $87.7 \%$ of the import share. Although, some of the Indonesia export commodity still has higher tariff, more than 10 percent or 12.3 percent of the India's imports from Indonesia. This indicates that it is more important to analyze the NTMs to get a better understanding of bilateral trade between Indonesia and India.

TABLE 2. SUMMARY OF INDIA'S TARIFF FOR PRODUCTS ORIGINATING FROM INDONESIA, AS PER 2018

\begin{tabular}{|c|c|c|c|c|}
\hline Range of Tariff & $\begin{array}{c}\text { Number of } \\
\text { products on } \\
\text { HS } 6 \text { Digit }\end{array}$ & $\begin{array}{c}\text { Share of } \\
\text { Product } \\
(\%)\end{array}$ & $\begin{array}{c}\text { Import } \\
\text { Value } \\
\text { (USD } \\
\text { Billion) }\end{array}$ & $\begin{array}{c}\text { Share of } \\
\text { Import } \\
(\%)\end{array}$ \\
\hline $0 \%$ & 1,227 & 73 & 13.1 & 66.6 \\
\hline $0 \%<x<5 \%$ & 286 & 17 & 1.0 & 5.2 \\
\hline $5 \%<x<10 \%$ & 32 & 2 & 3.1 & 15.9 \\
\hline $10 \%<X<20 \%$ & 84 & 5 & 1.8 & 9.0 \\
\hline $20 \%<X<50 \%$ & 32 & 2 & 0.6 & 2.9 \\
\hline $50 \%<X<100 \%$ & 16 & 1 & 0.1 & 0.3 \\
\hline$X>100 \%$ & 3 & 0 & 0.0 & 0.0 \\
\hline Total & 1,680 & 100 & 19.7 & 100 \\
\hline
\end{tabular}

According to Singh et al. (2018), Beghin et al. (2012), Baylis et al. (2010) and Disdier (2010), NTMs are now a very important aspect in terms of controlling the worldwide trade in commodities [14] [15] [16] [17]. The table 3 identifies the classifications of NTMs that India imposed to Indonesia. A total of 274 measures enacted consisting of 72 NTMs in the form of SPS, 46 NTMs in the form of TBT, 32 NTMs in the form of export measures, and 116 in the form of other measures for all countries; and 8 NTMs in the form of other measures for bilateral India and Indonesia. So, there are $27.1 \%$ of the SPS, $17.3 \%$ of TBT, $12 \%$ of export measures and $43.6 \%$ of other measures for all countries and 
$100 \%$ of other measures for bilateral (India NTMs imposed to Indonesia).

There is indication that India imposed SPS higher than TBT and Export Measures because the relevant authorities want to make sure that the India local markets is getting good quality of commodities that good for public health, especially for palm oil commodity (the same thing happened in AsiaPacific economies that imposed more SPS compared to other NTMs [27]). Second biggest Indonesian export to India is palm oil and its fractions (HS code 1511) about 3.6 billion USD equals to $23 \%$ of total Indonesian export to India.

\section{TABLE 3. CLASSIFICATIONS OF NTMS IMPOSED BY INDIA ON} INDONESIAN INTEREST

\begin{tabular}{lccccc}
\hline \multirow{2}{*}{ Partner Affected } & \multicolumn{5}{c}{ Classifications of NTMs (number) } \\
\cline { 2 - 6 } & SPS & TBT & $\begin{array}{c}\text { Export } \\
\text { Measures }\end{array}$ & $\begin{array}{c}\text { Other } \\
\text { Measures }\end{array}$ & Total \\
\hline All Countries & 72 & 46 & 32 & 116 & 266 \\
\hline Bilateral & 0 & 0 & 0 & 8 (CTPM) & 8 \\
$\begin{array}{l}\text { India to } \\
\text { Indonesia) }\end{array}$ & & & & & 124 \\
\hline Total & 72 & 46 & 32 & 274 \\
\hline
\end{tabular}

Table 4 shows the classifications of NTMs that Indonesia imposed to Indian interest. A total of 590 measures enacted consisting of 2 kinds of partner affected: all countries and bilateral (Indonesia NTMs imposed to India). The NTMs imposed by India for all countries (included Indonesia) consisting of 116 NTMs in the form of SPS, 311 NTMs in the form of TBT, 74 NTMs in the form of export measures, 68 NTMs in the form of other measures; and for bilateral (Indonesia NTMs imposed to India) consisting of 9 NTMs in the form of SPS, 7 NTMs in the form of TBT, 5 NTMs in the form of other measures. So, there are $21.2 \%$ of SPS, $53.9 \%$ of TBT, $12.5 \%$ of export measures and $12.4 \%$ of other measures.

The Normative Juridical Analysis of NTMs found that India has applied more Sanitary and Phytosanitary (SPS) policy to other countries (see table 3), but Indonesia has applied more Technical Barriers to Trade (TBT) policy to other countries. Although for bilateral trade, India has applied more Contingent Trade Protective Measures (CTPM) to Indonesia, but Indonesia has applied more Sanitary and Phytosanitary (SPS) to India (see table 4).

TABLE 4. CLASSIFICATIONS OF NTMS IMPOSED BY INDONESIA ON INDIAN INTEREST

\begin{tabular}{|c|c|c|c|c|c|}
\hline \multirow[b]{2}{*}{ Partner Affected } & \multicolumn{4}{|c|}{ Classifications of NTMs (number) } & \multirow[b]{2}{*}{ Total } \\
\hline & SPS & TBT & $\begin{array}{c}\text { Export } \\
\text { Measures }\end{array}$ & $\begin{array}{c}\text { Other } \\
\text { Measures }\end{array}$ & \\
\hline All Countries & 116 & 311 & 74 & 68 & 569 \\
\hline $\begin{array}{l}\text { Bilateral } \\
\text { (Indonesia to } \\
\text { India) }\end{array}$ & 9 & 7 & 0 & 5 & 21 \\
\hline Total & 125 & 318 & 74 & 73 & 590 \\
\hline
\end{tabular}

The application of NTMs in India is not as much in Indonesia so that Indonesia is relatively easier to carry out export activities to India. However, in developing trade to
India, it is necessary to pay attention to NTMs related to SPS because Indian NTMs related to SPS are higher than TBT. There are some things that hinder outside NTMs factors to conduct Trade with India, especially trade cost related to logistics, administrative costs and differences in perceptions among customs officials.

The descriptive analysis of NTMs can use various approaches (Dean et al., 2009; Cadot and Gourdon, 2016, Ferrantino, 2009; Fontagné et al., 2013; Francois et al., 2013; and Egger et al., 2015): simple inventory measures computation of price gaps [18] [19] and the estimation of ad valorem equivalents [20] [21] [22] [23]. Based on UNCTAD (2012), and CEPII (2014), simpler approach is based on two indices: the frequency index and the coverage ratio [2] [24]. These approaches purposes are to identify the importance of NTMs and assessing their effects on international trade.

The frequency index accounts only for the presence or absence of an NTM and summarizes the percentage of products to which one or more NTMs are applied (see table 5 ). Frequency index of NTMs imposed by country $j$ for product $i$ is formulated as follows (CEPII, 2014):

$$
F_{j}=\left[\frac{\sum D_{i} M_{i}}{\sum M_{i}}\right] \cdot 100
$$

Where $D$ is a dummy variable reflecting the presence of one or more NTMs and $M$ indicates whether there are imports of good $i$ (also a dummy variable).

$$
C_{j}=\left[\frac{\sum D_{i} V_{i}}{\sum V_{i}}\right] \cdot 100
$$

A measure of the importance of NTMs on overall imports is given by the coverage ratio, which measures percentage of trade subject to NTMs for the importing country $j$. In formal terms the coverage ratio is given by (CEPII, 2014):

$$
C_{j}=\left[\frac{\sum D_{i} V_{i}}{\sum V_{i}}\right] \cdot 100
$$

Where $D$ is defined as before, and $V$ is the value of imports in product $i$.

Furthermore, there are several challenging obstacles that need to be handled by two countries other than NTMs issue such as: (1) The logistic cost in both countries still more expensive compared to other neighboring countries; (2) there is still a considerable amount of regional/state retribution imposed on business actors and is considered burdensome; (3) there are still differences in perceptions between customs officials ([25] different perception of officials to implement government regulation also happened in the research from Jati and Wicaksena (2017)). The obstacles should be reduced by a specific strategies to develop the trade between Indonesia and India. 
TABLE 5. NTMS IMPOSED BY INDONESIA PER SECTOR (NTMS IMPOSED FOR ALL COUNTRIES)

\begin{tabular}{ccccc}
\hline Sector & $\begin{array}{c}\text { NTMs } \\
\text { Coverage } \\
\text { ratio }(\%)\end{array}$ & $\begin{array}{c}\text { NTMs } \\
\text { Frequency } \\
\text { ratio }(\%)\end{array}$ & $\begin{array}{c}\text { NTMs } \\
\text { affected } \\
\text { product } \\
\text { - count }\end{array}$ & $\begin{array}{c}\text { NTMs } \\
\text { affected trade } \\
\text { (USD } \\
\text { Billion) }\end{array}$ \\
\hline Animal & 100.0 & 100.0 & 225 & 2.6 \\
Vegetable & 99.3 & 91.8 & 290 & 7.2 \\
Food Products & 98.8 & 99.0 & 199 & 7.0 \\
Fuels & 96.6 & 28.2 & 11 & 29.8 \\
Transportation & 82.7 & 58.9 & 76 & 6.9 \\
Textiles and Clothing & 80.6 & 78.2 & 612 & 6.7 \\
Hides and Skins & 77.8 & 76.6 & 49 & 0.5 \\
Chemicals & 69.6 & 54.5 & 413 & 11.1 \\
Footwear & 63.3 & 53.2 & 25 & 0.3 \\
\hline All Import Products & 69.0 & 56.3 & 2,797 & 108.2 \\
\hline
\end{tabular}

Descriptive Analysis about NTMs can describe as a development strategy of the trade that can be implemented as follows: (1) NTBs should be removed, while NTMs should be streamlined (Indonesia better focus of top 5 biggest NTMs coverage ratio and frequency ratio in table 5); (2) it is necessary to do trade facilitation in order to speed up the efficiency and effectiveness of trade procedures between Indonesia and India and also reduce the cost of trade (Indonesia should evaluate the top 2 biggest NTMs affected trade for fuels and chemicals sectors in the table 5). (3) the policy of NTMs aims is to protect the safety of humans, animals, plants and also to improve the quality of life so that they can be competitive (relevant authorities should focus on animal and vegetable sectors in table 5). Problems increase when every countries make new regulations that result in trade relations being hampered [28]. Indonesia and India trade tend not to experience a very serious problem, even if there are constraints, trade facilitation needs to be improved, such as the availability of data and information [26], increase the role of relevant authorities to facilitate business actors, such as providing certification institution whose quantities and quality can be accepted by both countries. Most important is making the authorities rules and regulations need to involve all the stakeholders.

NTMs is the prerogative right of each country in its implementation, but do not let the NTMs turn into NTBs. It is essential to increase the trade facilitation between the two countries in order to develop new strategies of trade and the application of NTMs especially intended for the safety of Humans, Animals and Plants.

\section{CONCLUSIONS AND POLICY IMPLICATION}

It can be identified that India more implementing other measures to secure their domestic interest whereas Indonesia more implementing TBT. However, based on Normative Juridical Analysis, India has applied more SPS policy to other countries. Otherwise, Indonesia has applied more TBT policy to other countries. In bilateral trade, India has applied more CTPM, to Indonesia, whereas Indonesia has applied more SPS to India.

Furthermore, India and Indonesia face several obstacles that need to improve in their trading strategy other than NTMs issue such as logistic cost, burdensome retribution, and customs coordination between two countries. Moreover, based on Descriptive Analysis, it can be proposed as a development strategy that can be implemented by the two countries as follows (1) remove NTBs and streamline NTMs; (2) encourage trade facilitation in their trading activities [27]; (3) address NTMs as a policy to protect the safety of humans, animals, plants and also to improve the quality of life, not as a policy to discourage trade activities.

The application of NTMs is very important in the midst of a global effort to reduce duties on imported products. Since prices become more affordable, the competition between domestic and imported products become real. Consumers in one hand are profited by the fact that goods are more available in the market. However, state obligation is to administer the wider public interest, included the safety and the security of consumer when utilizing any products, domestic and import.

NTMs appear not primarily as a barrier of entry for imported products. Yet, it is meant to become the guidance and principles to protect the safety and security application of products to consumers. The main principle is National Treatment, which means that such measures are applied both for the domestic and international products.

The descriptive analysis as discussed in this paper show that both countries are actively imposed technical requirements on non agriculture products and follows the international principles of SPS on the agricultural products. Therefore, due to the high awareness of NTMs in both countries, Indonesia and India need to apply internationally accepted standard and treatment on its exported products, both agriculture and non-agriculture, to avoid unnecessary interception and rejection of entry to each other custom territory. Also, it is advisable that both countries follow any development of international rules of technical regulation and SPS to be implemented in their products, specially export oriented products.

\section{ACKNOWLEDGMENT}

On this special occasion, the researchers would like to thank the Head of Trade Analysis and Development Agency and Director of International Trade Cooperation Research Center-Ministry of Trade of Republic of Indonesia.

\section{REFERENCES}

[1] R. Baldwin, "Non-Tariff Distortions in International Trade Barriers", OECD Working Paper No.179, Paris, OECD, 1997.

[2] UNCTAD, "Non-Tariff Measures to Trade: Economic and Policy Issues for Developing Countries", Working Paper UNCTAD, 2013

[3] R. Mehta, "Non-tariff Barriers Affecting India's Export", RIS Discussion Papers, RIS-DP\#97,New Delhi, India, 2005.

[4] World Bank, "India's Economic Fundamentals Remain String; Investment Pick-up Needed for Sustained Growth, Says New World Bank Report”, Press Release, May 29, 2017.

[5] A. Gorener, "Comparing AHP and ANP: An Application of Strategic Decisions Making in a Manufacturing Company". International Journal of Business and Social Science, Vol.3, No.11: 194-268.

[6] BPPKP, "Kajian Penyusunan Strategi Pengembangan Ekspor Indonesia 2015-2019". Laporan Akhir BPPKP Kemendag, 2-14, 2014. [in Indonesian].

[7] IDDRI, “An Overview of India's Trade Strategy", Report of IDDRI, I 27, Rue Saint-Guillaume, Paris, France, March 2010.

[8] Embassy of India, "India-Indonesia Bilateral Relations", Unclassified Report of Embassy of India in Jakarta, 2018. 
[9] Purnamawati, I G.A., Yuniarta, G.A., Sulindawati, N.L.G.E. "Legal Protection of Geographical Indications of Traditional Crafts for Strengthening Regional Economic". IJEBL, Vol. 10, Issue 3, 2016.

[10] SAARCH, "Non-Tariff Measures and Non-Tariff Barriers in the SAARC Region", Report of SAARC Trade Promotion, 2016.

[11] ERIA, "Non-Tariff Measures in ASEAN", Working Paper, Economic Research Institute for ASEAN and East Asia and UNCTAD, 2016.

[12] Tongco, M.D.C. "Purposive Sampling as a Tool for Informant Selection", Ethnobotany Journal, retrieved 23 August 2019 from http://www.ethnobotanyjournal.org/vol5/i1547-3465-05-147.pdf.

[13] Peraturan Pemerintah, "PP Number 4 Year 2016 about Bringing Livestock and / or Animal Products in Certain Things Coming from the Country or Zone in a Country of Origin", Government Regulation Republic of Indonesia, 2016. [in Indonesian].

[14] Singh, R., Sharma, S., Tandon, D. "Non-Tariff Measures in India Context and European Union”. IJEF, Vol 10(9), 2018.

[15] Beghin, J. C., Disdier, A. C., Marette, S., \& Van, T. F. "Welfare costs and the benefits of non-tariff measures in trade: a conceptual framework and application". World Trade Review, 11(33), 2012.

[16] Baylis, K., Nogueira, L., \& Pace, K. "Food Import Refusals: Evidence from the European Union". American Journal of Agricultural Economics, 93(2), 566-572, 2010.

[17] Disdier, A. C., \& Marette, S. "The combination of gravity and welfare approaches for evaluating non-tariff measures". American Journal of Agricultural Economics, 92(3), 713-726, 2010.

[18] Dean, J.M., J. Signoret, R. Feinberg, R. Ludema and M. Ferrantino. "Estimating the Price Effects of Non-Tariff Barriers". The B.E. Journal of Economic Analysis \& Policy, Vol. 9, No. 1, 2009.

[19] Cadot, O. and Gourdon, J. Non Tariff Measures, Preferential Trade Agreement and Price: New Evidence. Review of World Economics, 152 (2), 227-249. https://doi.org/10.1007/s 10290-015-0242-9, 2016.

[20] Ferantino, M.J. "Methodological approaches to the quantification of non-tariff measures", chapter IX in Mia Mikic with Martin
Wermelinger (eds), Rising Non-Tariff Protectionism and Crisis Recovery, study by the Asia-Pacific Research and Training Network on Trade (ARTNeT) of the UN ESCAP, 2009.

[21] Fontagné, L., J. Gourdon and S. Jean. "Transatlantic Trade: Whither Partnership, Which Economic Consequences?", CEPII Policy Brief No. 1, CEPII, Paris, 2013.

[22] Francois, J., M. Manchin, H. Norberg, O. Pindyuk and P. Tomberger (2013), "Reducing Transatlantic Barriers to Trade and Investment An Economic Analysis", Report of EC TRADE10/A2/A16, 2013.

[23] Egger, P., J. Francois, M. Manchin and D. Nelson. "Non-tariff barriers", Economic Policy, Vol. 2, 2015

[24] CEPII. "Databases and Models", Report of CEPII Research and Expertise on the World Economy, 2014.

[25] Jati, Kumara., and Wicaksena, B. "Implementation of the Government Regulation Annual Financial Statements of the Company", Prosiding SNaPP: Sosial, Ekonomi dan Humaniora, Unisba, 2017.

[26] Jati, Kumara., and Laksani, D.D., "The Role of the Digital NTMs Data on Increasing Exports (Case Study: Brunei, Chile and Peru)", The $2^{\text {nd }}$ ICCAP Proceeding, Kemendag, 2018.

[27] Jati, Kumara., et al. "NTMs dan Trade Facilitation untuk Produk CPO yang Termasuk Kelompok Development Products Indonesia di AsiaPasifik" Laporan Akhir BPDP KS, Juni 2017. [in Indonesian].

[28] Jati, Kumara., et al., "The Role of Trade Cooperation between ASEAN \& India in Political Economy for Sustainable Development", Prosiding Seminar Nasional DPR RI, 2019a. [in Indonesian].

[29] Jati, Kumara., et al., "New Digital Era to Predict the Movement of Stock Price Index in Indonesia and India", Prosiding Seminar Nasional DPR RI, 2019b. [in Indonesian].

[30] Peraturan Presiden, "Pengesahan Agreement on Trade in Goods Under FTA on Comprehensive Economic Cooperation Between ASEAN \& India”, Perpres No. 27 tahun 2010, [in Indonesian]. 